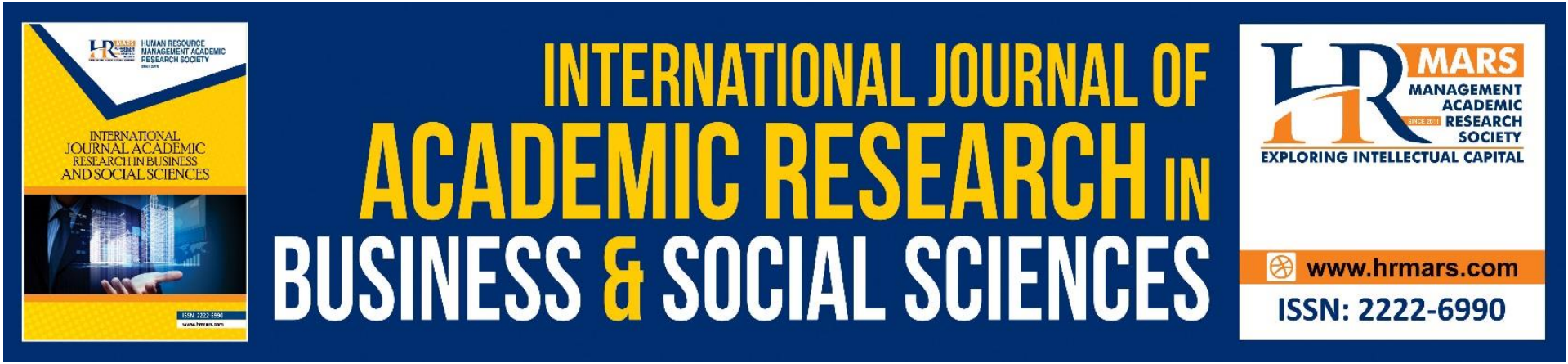

\title{
Factors That Influencing Project Management Performance: A Review
}

\author{
Majid Al-Nabae, Dania Sammani
}

To Link this Article: http://dx.doi.org/10.6007/IJARBSS/v11-i8/10332

DOI:10.6007/IJARBSS/v11-i8/10332

Received: 11 June 2021, Revised: 19 July 2021, Accepted: 01 August 2021

Published Online: 17 August 2021

In-Text Citation: (Al-Nabae \& Sammani, 2021)

To Cite this Article: Al-Nabae, M., \& Sammani, D. (2021). Factors That Influencing Project Management

Performance: A Review. International Journal of Academic Research in Business and Social Sciences, 11(8), 628-643.

Copyright: (c) 2021 The Author(s)

Published by Human Resource Management Academic Research Society (www.hrmars.com)

This article is published under the Creative Commons Attribution (CC BY 4.0) license. Anyone may reproduce, distribute, translate and create derivative works of this article (for both commercial and non-commercial purposes), subject to full attribution to the original publication and authors. The full terms of this license may be seen

at: http://creativecommons.org/licences/by/4.0/legalcode

Vol. 11, No. 8, 2021, Pg. 628 - 643

http://hrmars.com/index.php/pages/detail/IJARBSS

JOURNAL HOMEPAGE

Full Terms \& Conditions of access and use can be found at http://hrmars.com/index.php/pages/detail/publication-ethics 


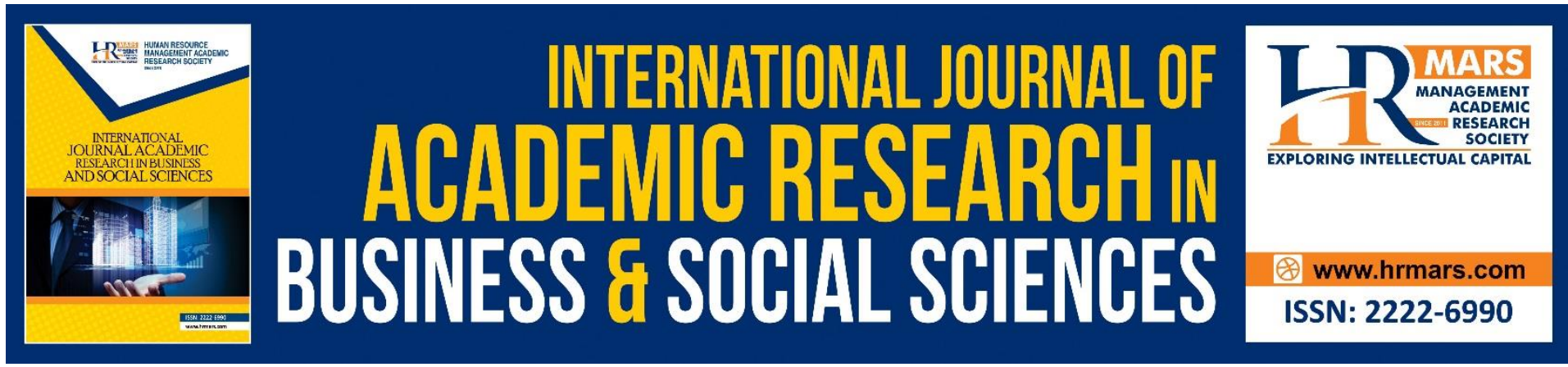

\title{
Factors That Influencing Project Management Performance: A Review
}

\author{
Majid Al-Nabae ${ }^{1}$, Dr. Dania Sammani² \\ ${ }^{1}$ PhD Students, Project Management Department, Faculty of Arts \& Science, \\ International University of Malaya-Wales, Kuala Lumpur, Malaysia, ${ }^{2}$ Senior lecturer, \\ Project Management Department, Faculty of Arts \& Science, International University of \\ Malaya-Wales, Kuala Lumpur, Malaysia. \\ Email: majidsaad2014@gmail.com,daniasammani@iumw.edu.my
}

\begin{abstract}
Optimal project performance is vital to success and avoid delay. Assessing projects improve their performance by providing accurate feedback to team members and managers. To construct an assessment tool that is both valid and reliable, it is necessary to understand what should be measured .The purpose of this paper is to introduce a review on how to measure performance in the project and to determine factors that influenced the project performance.

The present paper focuses on the importance of project performance and the factors that influence on project performance. It also offer valuable information to the researchers in the field of project management. The outcome of this study introduces a literature review for project performance according to the previous studies in the field of project management. The analysis of the literature contributes to the body of knowledge on the subject of project management and factors that influenced project performance.
\end{abstract}

Keywords: Project Management, Project Performance, Project Performance Factors.

\section{Introduction}

Project management performance holds great value, particularly because of its emphasis on continuous improvement via different project types. The primary objective behind project performance is to increase the success of the project's outcome and thus, this calls for a frame of reference in understanding what is exactly meant by project success. Performance refers to the achievement and fulfillment of operations relating to a set of goals and successful project achievement is possible through the team members' maintenance of high-quality performance and effective skills to achieve project activities (e.g. Procurement, communication and support project integration) (Mohamed et al., 2017). In addition, It refers to the process of generating positive outcomes, which explains how management decisions can affect performance (Anderson \& Lannon, 2019). It has been described by Horner et al (2014) as the barrage of advantages that comes from project implementation. 
Organizations are faced with several challenges that require enhancing the quality of their workforce for global level competition, as workforce is a core factor in organizations. Organizational performance is a complex concept that is affected by several constructs within the organization and in the environment ( $\mathrm{Ri}$ et al., 2015). Suffice it to say that the human resources of the organization are its most critical tool to enhance performance, enabling its competition and excellence in the competitive market (Jha, 2016). In fact, among the top reasons behind failed projects is poor and ineffective project requirements and engineering practice (Yang, 2017). Successful projects, based on some studies, depend on time, scope and cost, but in reality, it covers other elements like acceptance of clients, reputation of the firm, the match between business strategies, ethical attitude, unity of the project team members and others (Bonghez \& Grigoroiu, 2013; Picciotto, 2020).

The efforts towards measuring project performance needs clear definition and accurate measurement in order to correctly understand and monitor project operations (Decotiiset al., 2017). Prior practice shows that project performance is referred to as comprising of the triple constraints, namely quality, time and cost (Sunindijo, 2015).Project management performance indicators are obtained from tactical and limited time perspectives, based on quantitative measurements (cost, time and effort variance) and number defects (Bernardo, 2014). Performance of short-term projects is the achievement of project, including project efficiency and timely success of the project, while long-term project performance is the potential created by the project for further future projects. Long and short-term facets of project success measures can be comparable to the sequential nature of product improvement projects (Popaitoon \& Siengthai, 2014).Generally speaking, project performance is directly influenced by work quality in the phase of requirements analysis (Xiang et al., 2016). Factors that are present in the society and institution are also deemed as main determinants of the performance of multinational teams (Sağ et al., 2016).

\section{Literature Review}

\section{Performance Definition}

Performance is a concept that has been referred to as the goods/services generated during a specific period of time, based on the objectives. Two factors of performance that are significant are effectiveness and efficiency, and performance encapsulates the employee's efforts to achieve both factors (Kara, 2018). Employee performance is also described as the way employees realize goals of the organization and relate their inter-personal activities to the standards established within the organization (Osman et al., 2016).There are four main elements to organizational performance, namely general performance, technical performance, administrative performance and human performance (Ratnawat \& Jha, 2019). In relation to this, inter-organization collaboration enables the exchange of resources and knowledge and leveraging the advantages of knowledge integration and specialization as they positively affect innovation performance. Hence, innovation performance brings about the enhanced performance of the organization (Cho et al., 2017).

\section{Project Performance Measurement}

Project employee performance represents the skills, behaviors, knowledge and values held by the employee (Rafiei \& Davari, 2015) and because skills and abilities contribute to the performance of the organization and its productivity, any incurred training and development costs are deemed to be a long-term investment from which benefits can be reaped. Also, Muda, Rafiki, \& Harahap (2014) claimed that performance of employees forms one of the 
factors that can be utilized for the assessment of organizational performance via employee productivity, which means employee performance is the organization's capacity of achieving goals. In regards to this, performance appraisal practices represent HRM activities that produce critical data, for decision-making regarding HR actions and results ( $\mathrm{Yu} \&$ Cheng, 2014). Moreover, good level of employee performance is indicative of the employee's ability to contribute value to the organization through achievement of tasks (Muda et al. 2014). Within the organization, the innovative activities promoted influence the performance of employees and the operations and production as well as supplier connections and logistics (process innovation), particularly in innovative organizations and the bigger the size of the organization, the higher will be the number of cooperative partnerships it will have achieved (Cho et al., 2017). Prior studies in literature reached to the conclusion that training and development influence the performance of employees (e.g., Rragón, Jiménez, \& Valle,2014; Emenike et al., 2017).Other studies evidenced the role of training in enhancing employee performance (Seidle et al., 2016) and thus, training enhances both the organization's overall performance and productivity (Bhanugopan et al., 2017).

Traditional financial indicators take the form of earnings, profitability, market share and growth rate and these factors were used to gauge the performance of the organization. Nevertheless, there is another performance indicator type (non-financial indicator) that needs to be considered when measuring performance and this can be measured through quality, absenteeism of employees, turnover, job satisfaction and productivity (de Carvalho et al., 2015). Project performance measurement is complicated owing to the different utilized metrics in different projects (Looy \& Shafagatova, 2016).Employee performance measurement has taken on a significant status as a cross-disciplinary topic in IS and management fields. Performance management system generally gauges the achievement of institutions using performance indicators of the effectiveness and the efficiency of managerial processes (Anderson \& Lannon, 2019). Generally speaking, if a successful project is successful in its performance when it fulfilled its objectives, within the appropriated budget, planned quality, scheduled period and while making sure that stakeholders are all satisfied (Maqbool et al., 2017). Thus, an effective performance measurement is crucial to project success (Oforikuragu et al., 2015). Key performance indicators improvement contributes to the delivery of excellent project management processes and should thus be deemed as the characteristics of the project (Cha \& Kim, 2018).

In the same way, project management implementation maturity should be measured using an effective framework that focuses on performance improvement (Miklosik, 2015). As stated by Rui et al (2017) performance measurement metrics is a crucial element of project assessment system in order to establish a benchmark for the performance of the project from different points of view. In the same study caliber, project managers were found to make use of time and cost as a measurement as projects generally address their success through them under a limited scope Sanchez, Terlizzi, \& de Moraes (2017). Specifically, cost performance is considered as a major metric to identify if the project is successful because cost is the final result of the scope of the project (Rui et al., 2016). Schedule performance is equally significant as the construction costs incur labor wages and salaries of human resource ( Thompson et al., 2017). Added to this, project complexity is another determinant of project management performance, measured by the budget and schedule outcome (Bjorvatn \& Wald, 2018). With regards to the topic, Silver et al (2016) related that a skilled team equipped with problemsolving, change management, and effective leadership is the first step to performance evaluation while Das \& Ngacho (2017) added that the above is apart from the traditional 
project performance criteria of cost, time and quality. In other words, a team measurement system gauges the team's individual characteristics (skills, knowledge, abilities and the like), team work and task work processes states of conflict, collaboration, communication and cohesion, coupled with team outcomes (Wiese \& Florida, 2015). From Ofori-kuragu et al. (2016), a set of nine key performance indicators (KPIs) were proposed, which included cost, quality, client satisfaction, time, business performance, health and safety, people, productivity and lastly, environment.

High level of business competitiveness in the market needs quality and performance assessment so that companies can effectively evidence the enhancement of work quality (Willar, 2017). Successful project leads to advancements in the tools, processes and systems of project management (Mir \& Pinnington, 2014).

Furthermore, measurement of project performance entails the determination of a group of measures, measuring the aspects/factors that service users and stakeholders' find significant, and staff involvement in identifying the measures to ensure that perception measures and quantifiable performance indicators are all covered (Ofori-kuragu et al., 2016). In addition to the above, Ofori-kuragu et al (2016) further stated that performance measures refer to a group of metric utilized to quantify the actions based on effectiveness and efficiency and they are the basis of determining and defining the operational improvements requirements in organizations (Al-kaisy et al., 2018). Teams' assessment will lead to their enhanced performance as they are presented with dependable and timely feedback (Marriage \& Kinnear, 2016). Thus, project management should place emphasis on the execution, overseeing, and controlling activities, using valid metrics to ensure successful outcome (Montero et al., 2015). Organizations need to be prepared to use performance indicators for the system projects control to garner authentic information, required for making decisions among governance positions and levels (e.g., executives, board level, contextual level and individual level) (Heinze \& Heinze, 2018). Industrial performance influences the economic performance and thus, it has to be measured and benchmarked for sustainable industry (Hwang, 2013).

In the same study line, a performance indicator metric for project performance measurement should be used along with KPIs includes the cost, schedule and quality that are the often KPIs used for performance measurement of the project (Yun et al., 2015). In a related study, Leong et al (2014) empirically provided five main variables for measuring the performance of projects, and they are cost performance, quality performance, time performance, safety and health performance, and finally, client's satisfaction. In the context of gas and oil projects, understanding cost performance was found by Rui et al. (2016) to be significant to controlling projects (present and future) and in the cost reductions implementation success. Additionally, risk management is the focus of project-basic firms, with its primary objective being to produce organizational value (Khameneh et al., 2016). The measurement of technological and non-technological innovation performance adopted in this study was obtained from prior innovation studies and they are increased efficiencies, innovation rate, administrative processes development and enhanced employee effectiveness (see Damanpour, 2014; Lau \& Lo, 2015; Osman et al., 2016). In relation to this, the benchmarking method develops satisfaction of the stakeholders of the project and provides data needed for the evaluation of the project that is useful for external and internal organizational benchmarking from the industry's point of view (Kärnä, 2016).

With regards, to audit performance, Zailani, Govindan, Iranmanesh, \& Shaharudin (2015) explained its requirement in several project types, although the current methods for 
establishing capital performance audit have high variability and formal standard are known to stress on engagement management rather than project management. Performance audit integral factors of economy, efficiency and effectiveness are also largely ignored in practical activities. A significant relationship exists between project progress management methods and on-time completion (Winter \& Chaves, 2017). In sum, the employees' performance considerably influences the project and the industry as a whole, and thus it has to be measured and benchmarked for sustainable economy (Hwang, 2013).

\section{Factors Influencing project Performance}

Integration management as well as other practices of project management is of great significance as the effectiveness of project management is initiated with the processes and people integration in the construction project to ensure performance enhancement (Demirkesen \& Ozorhon, 2017). For a successful project, it is mandatory to determine project success and its measurement and this requires knowledge sharing and communication to enhance the performance of cost, time and quality of the project (Lindhard \& Larsen, 2016). According to Fink (2014), the gaining of strategic positions and performance among firms necessitate specific firm competence compared to their rivals, and in light of projects, better governance of the numerous relevant factors and systems could lead to enhanced project performance (Haq et al., 2018).

Different elements are incorporated by projects such as technology, tools, methods and models out of which human element is the top element in projects that drives its performance (Zidane, Hussein, \& Orn, 2016) . Projects are efficiently completed through the execution of strategies by the project management and the summary of the whole work (An et al., 2018) and as such, the members of the project team needs to be motivated and committed to the successful project performance (Larsson, 2018). Also, the project performance in meeting success criteria is upped when the right procedures exist for the just treatment of the members of the team, when the resources are fairly distributed and when the members' interaction is based on respect, propriety and dignity (Unterhitzenberger \& Bryde, 2018). In this background, it is the culture that pre-determines the actions of the members and as such, the culture of the team members should be determined to take appropriate actions during project management (Horner et al., 2014). Project manager's importance lies in leadership as it is a major success factory in any activity involving collaboration among people (Lancker et al., 2016). The type of leadership that positively influences promotion focus is transformational leadership and that positively influences prevention focus in project team performance is transactional leadership (Lai et al., 2017).

In project management, performance measurement in the context of construction is also critical considering its impact on the global economy. Thus, effective project management is compulsory for higher construction performance (Demirkesen \& Ozorhon, 2017). In a similar study, Anantatmula (2015) revealed that governing policies and procedures, effective communication management plan and collaborative culture of the project should be established to enhance the performance of the project. ICT research in construction sector in the developing nation's context can contribute to providing insight into project performance and its enhancement (Ikediashi \& Ogwueleka, 2016).Added to the above, knowledge advancements are required to urge organizations to manage project team performance optimally (Liu \& Cross, 2016), with mega-projects being more sensitive to specific factors compared to their small-sized counterparts (Caldas \& Gupta, 2016). Management of largesized projects is however quite challenging as opposed to managing typical internal projects 
as evidenced by Patanakul (2014). Historically, infrastructure megaprojects are related with ineffective delivery in light of cost and schedule performance (Locatelli et al., 2017). As for the effective workflow management, it can be realized through the promotion of a reliable work-place via which planning strategies can facilitate the increase/decrease of the project duration, total capacity lost and total inventory buffer as reported in Javanmardi et al.'s (2016) study. Also of importance to project management are coordination factors that ensure successful project stages implementation (Alaloul et al., 2016). These are described by Oliveira \& Lumineau (2017) as activities set into motion and influence performance. Projects alliances frequently contribute superior value for money and value in general in comparison to traditional approaches (e.g., design and construct) (Henry et al., 2015).

In the same study line, Heckmann et al. (2015) revealed that the capacity of the organization to change is positively associated with change project's performance. Enhanced organizational performance can be achieved through ensuring consistent quality enhancements, cost optimization and productivity, flexibility and safety enhancements and timely deliveries (Randhawa \& Ahuja, 2017). Risks arising from performance indicators can be mitigated through strategies adopted consistent with the complexity type and level (Floricel et al., 2016). Both project performance and project management can be measured by the level to which constraints are overcome to satisfy the objectives of the project (scope, time and cost) - such overcoming is the key to successful project management (Rugenyi \& Bwisa, 2016). They have been referred to as the project management triangle, iron triangle, and project triangle. In relation to this, high-cost overruns and schedule delays prevent the motivation of oil and gas firms to invest in the face of risky opportunities (Rui et al., 2018). In addition, customer base also limits the internal financing of the firm and the investment on R\&D (Notari et al., 2014). In this background, incentive contracts have a higher likelihood to display better performance compared to those without incentives as the former promotes better relational attitudes and quality in teamwork (Suprapto et al., 2015).

In the case of international construction, ongoing challenges in achieving project cost and time performance have been reported by contractors, which is frequently related to using different foreign standards that are significant different from the local standards (Lei et al., 2017). Diethelm et al. (2016) found that the higher the percentage of prevention practices established through a strategy, the lower is the rate of accidents, and the higher the enhancement level of safety performance. Safety performance is determined by management activities within the stages of the project and the interactions of factors at different levels of hierarchy (Mohammadi et al., 2018). In other related studies, Horner et al.(2014) and Smits, Buiten, \& Hartmann (2016) found knowledge and information to significantly influence the performance of employees in projects. Project management knowledge value is related to the analysis and positioning tool usage to enhance the performance of project management (Brookes et al., 2014). Along the same study line, Wang et al.(2018) stated that project management requirement of coordination and integration of bilateral exertions of client and its provider is rife with challenges, whereas Rui et al. (2017) highlighted the influence of regulatory requirements and political climate on the performance of $O \& G$ projects. The above mentioned factors significantly and in combination affect offshore projects and result in higher complexity and interfaces compared with other industries' projects. Stakeholders also have a key role in successful project management (Aragonés-beltrán et al., 2017), with stakeholder management (SM) involving the engagement of project management research domain and the concerned industry (Oppong et al., 2017). 


\section{Methodolodgy}

The paper takes account the review of related literature allocated to project performance and project empolyee performance to achieve the study objectives. The review covers the defention of performance and project employee perforamance. The research basically focuses on explaining how to measure performance in the project and the factors that influenced the employee performance.

\section{Findings and Discussions}

The present study conducted a thorough review of literature for the previous studies to provide an overview of factors that influence the project performance and found that employs different measures leading to different definitions. The studies by Kara (2018); Ofori-kuragu et al (2016); Osman et al (2016); Ratnawat \& Jha (2019) described effective performance measurement important to the success of the project. In prior studies, the relationship between the two has been statistically proven to be positive (e.g., Mir \& Pinnington, 2014; Rivera-ruiz \& Ferrer-moreno, 2015).The attainment of enhanced project performance is possible through adoption of innovation and skills training in order to improve the efforts towards performance (Wisdom et al., 2014). This is possible by placing emphasis on quality improvements, optimization of costs, productivity, flexibility, and safety enhancements and timely delivery (Horner et al., 2014; Kim \& Lui, 2015; Oppong et al., 2017; Randhawa \& Ahuja, 2017; Rui et al., 2017; Smits et al., 2016).More importantly, three deliverable objectives have been the traditional determinants of project performance, namely time, cost and quality and majority of studies presented significant performance measures which are also referred to as popular KPIs.

In the reviewed literature, performance measurement has been evidenced to be crucial to performance improvement efforts (Ofori-kuragu et al., 2016) and majority of studies, as mentioned, are of the consensus of the simplistic measure of performance through the costtime-quality triangle. Specifically, a performance measure refers to a metric utilized to quantify the action's efficiency and effectiveness (Randhawa \& Ahuja, 2017) . Organizational survival depends on its ability to provide creativity, innovation and inventive training to its employees so that they will work towards obtaining competitive advantage and enhanced performance (Abdullahi et al., 2018).

Training is an effective mechanism to bring about enhanced innovation in the firm as a result of which organizational performance is also enhanced. Adoption of innovation involves training and performance efforts, with innovation being the basis of the firm's achieving optimum performance.In sum, most of the previous studies' results support the idea that in the midst of these measures, cost, quality and time remain three of the essential measures for project performance. Other KPIs mentioned in literature include human resources, innovation, business performance, productivity, health and safety and environment (Anantatmula, 2015; Caldas \& Gupta, 2016; Ikediashi \& Ogwueleka, 2016; Leong et al., 2014; Liu \& Cross, 2016; Yun et al., 2015).

The prvious studies suggested that there are many factors that influnced project performance , according Horner et al (2014); Smits, Buiten, \& Hartmann (2016) knowledge and information is significantly influence the empolyee of projects. The members of the project team needs to be motivated (Larsson, 2018). Within this context,knowledge advancements are required to urge organizations to manage project team performance optimally (Liu \& Cross, 2016).Horner et al. (2014) proposed that the culture of the team members should be determined to take appropriate actions during project management. In addition a better 
governance of the numerous relevant factors and systems could lead to enhanced project performance (Haq et al., 2018). Diethelm et al. (2016) introduced an approach that the higher the percentage of prevention practices established through a strategy, the lower is the rate of accidents, and the higher the enhancement level of safety performance. In this sense, the study by Anantatmula (2015) found that governing policies and procedures, effective communication management plan and collaborative culture of the project should be established to enhance the performance of the project. According to Heckmann et al. (2015) revealed that the capacity of the organization to change is positively associated with change project's performance. Stakeholders also have a key role in successful project management (Aragonés-beltrán et al., 2017) . Training and development influence the performance of employees (e.g., Rragón, Jiménez, \& Valle, 2014; Emenike et al., 2017) and adoption of innovation is another stategy to improve project performance (Wisdom et al., 2014).

Along the same study line, Wang et al.(2018) stated that project management requirement of coordination and integration of bilateral exertions of client and its provider is rife with challenges, whereas Rui et al. (2017) highlighted the influence of regulatory requirements and political climate on the performance of O\&G projects. The above mentioned factors significantly and in combination affect offshore projects and result in higher complexity and interfaces compared with other industries' projects.

\section{Conclusion}

The literature review findings indicate that project performance has been traditionally viewed as having three major factors that influence the project perfroamcne namely time, cost and quality. However, other performance factors known as KPIs should also be taken into consideration as most of the authors laid emphasis on. Indubitably, cost, quality and time are significant project performance measures but along with them are KPIs of administrative business performance, productivity, people and environment. The paper concluded that there are many factors that influnced project performance as discussed in the previous studies, they are Training and human development (Rragón, Jiménez, \& Valle,2014; Emenike et al., 2017) knowledge and information, motivation (Larsson, 2018), team culture (Horner et al., 2014), innovation adoption (Wisdom et al., 2014), governance of the systems (Haq et al., 2018), safety and health practice and training (Diethelm et al. 2016) ,governing policies and procedures, effective communication management plan (Anantatmula (2015), knowledge advancement (Liu \& Cross, 2016), the capacity of the organization to change (Heckmann et al.,2015). coordination and integration of bilateral exertions of client and its provider (Wang et al.,2018), regulatory requirements and political climate (Rui et al.,2017), and Stakeholders management (Aragonés-beltrán et al., 2017). The importance of this study lies in the discussion of the most critical factors that impact project performance. The result of this study is expected to be of great value to the project managers and researchers in the field of project management and management in general. Future research should attempt to examin of the impact of thses factors on the project performance by using case studies, this type of method could help to study these relationships .

\section{References}

Abdullahi, M. S., Gwadabe, Z. L., \& Bature, M. (2018). Effect of training and development on employee's productitiy among academic staff of kano state polytechnic ,Nigeria. Asian People Journal (APJ), 1(2), 264-286. 
Al-kaisy, A., Jafari, A., Washburn, S., Lutinnen, T., \& Dowling, R. (2018). Performance measures on two-lane highways: Survey of practice. Research in Transportation Economics, July 2017, 1-7. https://doi.org/10.1016/j.retrec.2018.07.001

Alaloul, W. S., Liew, M. S., Amila, N., \& Abdullah, W. (2016). Identification of coordination factors affecting building projects performance. Alexandria Engineering Journal, 55(3), 2689-2698. https://doi.org/10.1016/j.aej.2016.06.010

An, N., Qiang, M., Wen, Q., Jiang, H., \& Xia, B. (2018). Contribution of project managers' capability to project ending performance under stressful conditions. European Management Journal. https://doi.org/10.1016/j.emj.2018.04.001

Anantatmula, V. S. (2015). Strategies for Enhancing Project Performance. Journal of Management in Engineering, 31(6), 04015013. https://doi.org/10.1061/(ASCE)ME.1943-5479.0000369.

Anderson, K., \& Lannon, J. (2019). Project Management Performance Assessment in the NonProfit Sector. Project Management Research and Practice, 5(2018), 1-20.

Aragón, M., Jiménez, D. J., \& Valle, R. S. (2014). Training and performance: The mediating role of organizational learning. BRQ Business Research Quarterly, 17(3), 161-173. https://doi.org/10.1016/j.cede.2013.05.003

Aragonés-beltrán, P., García-melón, M., \& Montesinos-valera, J. (2017). How to assess stakeholders ' in $\mathrm{fl}$ uence in project management ? A proposal based on the Analytic Network Process. International Journal of Project Management, 35(3), 451-462. https://doi.org/10.1016/j.ijproman.2017.01.001

Bernardo, R. (2014). Performance Indicators for enhancing Governance of Projects. Procedia - Social and Behavioral Sciences, 119, 55-64.

https://doi.org/10.1016/j.sbspro.2014.03.009

Bhanugopan, R., Wang, Y., Lockhart, P., \& Farrell, M. (2017). Managerial skills shortages and the impending effects of organizational characteristics. Personnel Review, 46(8), 16891716. https://doi.org/10.1108/PR-04-2016-0093

Bjorvatn, T., \& Wald, A. (2018). Project complexity and team-level absorptive capacity as drivers of project management performance. International Journal of Project Management, 36(6), 876-888. https://doi.org/10.1016/j.ijproman.2018.05.003

Bonghez, S., \& Grigoroiu, A. (2013). If it can ' t be expressed in figures-project performance management Performance Management - Overview. Paper Presented at $P M I^{\circledR}$ Global Congress 2013-EMEA, Istanbul, Turkey. Newtown Square, PA: Project Management Institute., April.

Brookes, N., Dey, M. B. and P., \& Clark, R. (2014). The use of maturity models in improving project management performance. International Journal of Managing Projects in Business, 7(2), 231-246.

Caldas, C., \& Gupta, A. (2016). Critical factors impacting the performance of mega-projects. Engineering, Construction and Architectural Management, 24(6), 920-934.

Cha, H. S., \& Kim, K. H. (2018). Measuring Project Performance in Consideration of Optimal Best Management Practices for Building Construction in South Korea. Journal of Civil Engineering (2018), 22(5), 1614-1615. https://doi.org/10.1007/s12205-017-0156-2

Cho, Y., Lee, C., \& Mok, E. (2017). The Effects of Cooperative Activities with Competitors on the Performances of Innovation and Management. Proceedings of the 2017 IEEE IEEM, 166-170.

Damanpour, F. (2014). Footnotes to research on management innovation. Organization Studies, 35(9), 1265-1285. https://doi.org/10.1177/0170840614539312 
Das, D., \& Ngacho, C. (2017). Critical success factors influencing the performance of development projects : An empirical study of Constituency Development Fund projects in Kenya. IIMB Management Review, 29(4), 276-293. https://doi.org/10.1016/j.iimb.2017.11.005

De Carvalho, M. M., Patah, L. A., \& de Souza Bido, D. (2015). Project management and its effects on project success: Cross-country and cross-industry comparisons. International Journal of Project Management, 33(7), 1509-1522. https://doi.org/10.1016/j.ijproman.2015.04.004

Decotiis, T. A., Dyer, L., Decotiis, T. A., \& Dyer, L. (2017). Defining and Measuring Project Performance. Research Management, 22(1), 17-22.

Demirkesen, S., \& Ozorhon, B. (2017a). Impact of integration management on construction project management performance. International Journal of Project Management, 35(8), 1639-1654. https://doi.org/10.1016/j.ijproman.2017.09.008

Demirkesen, S., \& Ozorhon, B. (2017b). Measuring Project Management Performance: Case of Construction Industry. Engineering Management Journal, 29(4), 258-277. https://doi.org/10.1080/10429247.2017.1380579

Diethelm, S., Pellicer, E., Fernando, L., \& Acu, D. (2016). Strategies for improving safety performance in construction firms. Accident Analysis and Prevention Journal, 94, 107118. https://doi.org/10.1016/j.aap.2016.05.021

Emenike, I. I., Uzoamaka, E. V., \& Nwosu, N. L. (2017). Effects of Training and Development on Employee Performance at Abia State Polytechnic, Aba. International Journal of Economics and Business Managemen, 3(9), 13-22.

Fink, L. (2014). The Impact of the Customer Focus Competence Group on Project Performance Article information : Research in Competence-Based Management, 117-143.

Floricel, S., Michela, J. L., \& Piperca, S. (2016). Complexity, uncertainty-reduction strategies, and project performance. International Journal of Project Management, 34(7), 13601383. https://doi.org/10.1016/j.ijproman.2015.11.007

Haq, S. U., Liang, C., Gu, D., Du, J. T., \& Zhao, S. (2018). Project Governance, Project Performance, and the Mediating Role of Project Quality and Project Management Risk: An Agency Theory Perspective. Engineering Management Journal, 30(4), 274-292. https://doi.org/10.1080/10429247.2018.1503038

Heckmann, N., Steger, T., \& Dowling, M. (2015). Organizational capacity for change , change experience, and change project performance. Journal of Business Research, 69(2), 777784. https://doi.org/10.1016/j.jbusres.2015.07.012

Heinze, K. L., \& Heinze, J. E. (2018). Individual innovation adoption and the role of organizational culture. Review of Managerial Science, 0123456789, 1-26. https://doi.org/10.1007/s11846-018-0300-5

Henry, D., Walker, T., Harley, J., \& Mills, A. (2015). Performance of Project Alliancing in Australasia : a Digest of Infrastructure Development from 2008 to 2013. Construction Economics and Building, 15(1), 1-18.

Horner, B., Gemino, A., \& Sauer, C. (2014). How knowledge management impacts performance in projects: An empirical study. International Journal of Project Management, 32(4), 590-602. https://doi.org/10.1016/j.ijproman.2013.09.004

Hwang, B. (2013). Capital project performance measurement and benchmarking in Singapore. Engineering, Construction and Architectural Management, 20(2), 143-159. https://doi.org/10.1108/09699981311303017 
Ikediashi, D. I., \& Ogwueleka, A. C. (2016). Assessing the use of ICT systems and their impact on construction project performance in the Nigerian construction industry. Journal of Engineering, Design and Technology, 14(2), 238-251.

Javanmardi, A., Abbasian-hosseini, S. A., Liu, M., \& Hsiang, S. M. (2016). Analysis of Workflow Variability ' $s$ Impacts on Trade and Project Performance. Procedia Engineering, 145, 281-287. https://doi.org/10.1016/j.proeng.2016.04.075

Jha, B. (2016). Employee Engagement : A Strategic Tool to Enhance Performance. Journal for Contemporary Research in Management, July, 21-29.

Kara, E. (2018). THE EFFECTS OF TOTAL QUALITY MANAGEMENT ON EMPLOYEES' PERFORMANCE: A STUDY ON TEXTILE BUSINESS. Business \& Management Studies: An International Journal, 6(3), 551-563.

Kärnä, S. (2016). Benchmarking construction industry, company and project performance by participants' evaluation. An International Journal, 23(7), 2092-2108.

Khameneh, A., Taheri, A., \& Ershadi, M. (2016). Offering a framework for evaluating the performance of project risk management system. Procedia - Social and Behavioral Sciences, 226(October 2015), 82-90. https://doi.org/10.1016/j.sbspro.2016.06.165

Kim, Y., \& Lui, S. S. (2015). The impacts of external network and business group on innovation: Do the types of innovation matter? Journal of Business Research, 68(9), 1964-1973. https://doi.org/10.1016/j.jbusres.2015.01.006

Lai, C., Hsu, J. S., \& Li, Y. (2017). Leadership, regulatory focus and information systems development project team performance. International Journal of Project Management, 36(3), 566-582. https://doi.org/10.1016/j.ijproman.2017.11.001

Larsson, J. (2018). The importance of hard project management and team motivation for construction project performance. International Journal of Managing Projects in Business, 11(2). https://doi.org/10.1108/IJMPB-04-2017-0035

Lau, A. K. W., \& Lo, W. (2015). Technological Forecasting \& Social Change Regional innovation system, absorptive capacity and innovation performance: An empirical study. Technological Forecasting \& Social Change, 92, 99-114.

https://doi.org/10.1016/j.techfore.2014.11.005

Lei, Z., Tang, W., Duf, C., Zhang, L., Kin, F., \& Hui, P. (2017). The impact of technical standards on international project performance : Chinese contractors ' experience. International Journal of Project Management, 35, 1597-1607. https://doi.org/10.1016/j.ijproman.2017.09.002

Leong, T. K., Zakuan, N., Mat Saman, M. Z., Ariff, M. S. M., \& Tan, C. S. (2014). Using Project Performance to Measure Effectiveness of Quality Management System Maintenance and Practices in Construction Industry. The Scientific World Journal, 2014. https://doi.org/10.1155/2014/591361

Lindhard, S., \& Larsen, J. K. (2016). Identifying the Key Process Factors Affecting Project Performance. Engineering, Construction and Architectural Management, 23(5), 657673.

Liu, W., \& Cross, J. A. (2016). A comprehensive model of project team technical performance. JPMA, 34(7). https://doi.org/10.1016/j.ijproman.2016.05.011

Locatelli, G., Invernizzi, D. C., \& Brookes, N. J. (2017). Project characteristics and performance in Europe: An empirical analysis for large transport infrastructure projects.

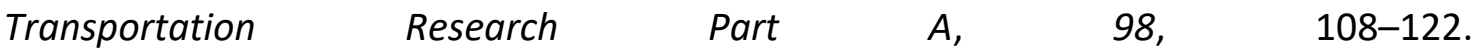
https://doi.org/10.1016/j.tra.2017.01.024 
Looy, A. Van, \& Shafagatova, A. (2016). Business process performance measurement: a structured literature review of indicators, measures and metrics. SpringerPlus, 5, 1797. https://doi.org/10.1186/s40064-016-3498-1

Maqbool, R., Sudong, Y., Manzoor, N., \& Rashid, Y. (2017). Transformational Leadership on Project Success : An Empirical Perspective. Project Management Journal, 48(3), 58-75. https://doi.org/10.1177/875697281704800304

Marriage, B., \& Kinnear, J. (2016). Assessing team performance - Markers and methods. Trends in Anaesthesia and Critical Care, 7, 1-6. https://doi.org/10.1016/j.tacc.2016.05.002

Miklosik, A. (2015). Improving project management performance through capability maturity measurement. Procedia Economics and Finance, 30(15), 522-530. https://doi.org/10.1016/S2212-5671(15)01264-2

Mir, F. A., \& Pinnington, A. H. (2014). Exploring the value of project management: Linking Project Management Performance and Project Success. International Journal of Project Management, 32(2), 202-217. https://doi.org/10.1016/j.ijproman.2013.05.012

Mohamed, M., Abuazoom, I., Hanafi, H. Bin, \& Ahmad, Z. Bin. (2017). Influence of HRM Practices on Project Performance: Conceptual Framework. 7(3), 47-54. https://doi.org/10.6007/IJARBSS/v7-i3/2691

Mohammadi, A., Tavakolan, M., \& Khosravi, Y. (2018). Factors in fl uencing safety performance on construction projects : A review. Safety Science, 109(December 2017), 382-397. https://doi.org/10.1016/j.ssci.2018.06.017

Montero, G., Onieva, L., \& Palacin, R. (2015). Selection and Implementation of a Set of Key Performance Indicators for Project Management. International Journal of Applied Engineering Research, 10(18), 39473-39484.

Muda, I., Rafiki, A., \& Harahap, M. R. (2014). Factors Influencing Employees' Performance : A Study on the Islamic Banks in Islamic banks in indonesia. International Journal of Business and Social Science, 5(2), 73-80.

Notari, M., Baumgartner, A., \& Herzog, W. (2014). Social skills as predictors of communication , performance and quality of collaboration in project-based learning. Journal of Computer Assisted Learning (2014), 30, 132-147. https://doi.org/10.1111/jcal.12026

Ofori-kuragu, J. K., Baiden, B. K., \& Badu, E. (2015). Key Performance Indicators for Project Success in Ghanaian Contractors. International Journal of Construction Engineering and Management, 5(1), 1-10. https://doi.org/10.5923/j.ijcem.20160501.01

Ofori-kuragu, J. K., Baiden, B. K., \& Badu, E. (2016). Key Performance Indicators for Project Success in Ghanaian Contractors. International Journal of Construction Engineering and Management, 5(1), 1-10. https://doi.org/10.5923/j.ijcem.20160501.01

Oliveira, N., \& Lumineau, F. (2017). How Coordination Trajectories Influence the Performance of Interorganizational Project Networks How Coordination Trajectories Influence the Performance of Interorganizational Project Networks. Organization Science.

Oppong, G. D., Chan, A. P. C., \& Dansoh, A. (2017). A review of stakeholder management performance attributes in construction projects. International Journal of Project Management, 35(6), 1037-1051. https://doi.org/10.1016/j.ijproman.2017.04.015

Osman, S., Shariff, S. H., \& Lajin, M. N. A. (2016). Does Innovation Contribute to Employee Performance? Procedia - Social and Behavioral Sciences, 219, 571-579. https://doi.org/10.1016/j.sbspro.2016.05.036 
Patanakul, P. (2014). Managing large-scale IS / IT projects in the public sector : Problems and causes leading to poor performance. Journal of High Technology Management Research, 25(1), 21-35. https://doi.org/10.1016/j.hitech.2013.12.004

Picciotto, R. (2020). Towards a 'New Project Management' movement? An international development perspective. International Journal of Project Management, 38(8), 474485. https://doi.org/10.1016/j.ijproman.2019.08.002

Popaitoon, S., \& Siengthai, S. (2014). The moderating effect of human resource management practices on the relationship between knowledge absorptive capacity and project performance in project-oriented companies. JPMA, 32(2), 202-217. https://doi.org/10.1016/j.ijproman.2013.12.002

Rafiei, N., \& Davari, F. (2015). The Role of Human Resources Management on Enhancing the Teaching Skills of Faculty Members. Materia Socio Medica, 27(1), 35. https://doi.org/10.5455/msm.2014.27.35-38

Randhawa, J. S., \& Ahuja, I. S. (2017). 5S - A QUALITY IMPROVEMENT TOOL FOR SUSTAINABLE PERFORMANCE: LITERATURE REVIEW AND DIRECTIONS. International Journal of Quality \& Reliability Management, 34(3 pp.), 334-361.

Ratnawat, R. G., \& Jha, P. C. (2019). Impact of Job Related Stress on Employee Performance : A Review and Research Agenda. IOSR Journal of Business and Management (IOSR-JBM), 16(11), 01-06. https://doi.org/10.9790/487X-161150106

Ri, I., Dqg, R., Rq, L., Hh, P., Lq, D. V. H., Dqjxq, V., Gdq, Q., Dulv, E., Buana, U. M., Ri, D. L. P., Vwxg, W. K. H., Wr, L. V, Wkh, G., Ri, H., Frpshwhqfh, W., Glvflsolqh, D. Q. G., Wkh, R. Q., Ri, S., Hhv, H., \& Lq, Z. (2015). Effect of Training, Competence and Discipline on Employee Performance in Company (Case Study in PT. Asuransi Bangun Askrida). Social and Behavioral Sciences, 211, 1240-1251. https://doi.org/10.1016/j.sbspro.2015.11.165

Rivera-ruiz, I., \& Ferrer-moreno, E. (2015). The Relationship Between Strategic Leadership , Human IT Infrastructure, Project Management, Project Success, and Firm Performance. International Journal of Information, Business and Management, 7(2), 9202.

Rugenyi, F., \& Bwisa, H. (2016). Effects of triple constraints on the management of projects in nairobi: the project managers' perspective. The Strategies Journal of Business \&change Management, 3(2 (16)), 344-367.

Rui, Z., Cui, K., Wang, X., Chun, J., Li, Y., Zhang, Z., Lu, J., Chen, G., Zhou, X., \& Patil, S. (2018). A Comprehensive Investigation on Performance of Oil and Gas Development in Nigeria: Technical and Non-Technical Analyses. Energy. https://doi.org/10.1016/j.energy.2018.06.027

Rui, Z., Li, C., Peng, F., Ling, K., Chen, G., \& Zhou, X. (2017). Development of industry performance metrics for offshore oil and gas project. Journal of Natural Gas Science and Engineering, 39, 44-53. https://doi.org/10.1016/j.jngse.2017.01.022

Rui, Z., Peng, F., Ling, K., Chang, H., Chen, G., \& Zhou, X. (2016). Investigation into the performance of oil and gas projects. Journal of Natural Gas Science and Engineering, 38, 12-20. https://doi.org/10.1016/j.jngse.2016.11.049

Sağ, S., Kaynak, R., \& Sezen, B. (2016). Factors Affecting Multinational Team Performance. Procedia - Social and Behavioral Sciences, 235(October), 60-69. https://doi.org/10.1016/j.sbspro.2016.11.025

Sanchez, O. P., Terlizzi, M. A., \& de Moraes, H. R. de O. C. (2017). Cost and time project management success factors for information systems development projects. 
International Journal of Project Management, 35(8), 1608-1626. https://doi.org/10.1016/j.ijproman.2017.09.007

Seidle, B., Fernandez, S., \& Perry, J. L. (2016). Do Leadership Training and Development Make a Difference in the Public Sector? A Panel Study. Public Administration Review, 76(4), 603-613. https://doi.org/10.1111/puar.12531.Do

Silver, S. A., Harel, Z., Mcquillan, R., Weizman, A. V, Thomas, A., Chertow, G. M., Nesrallah, G., Bell, C. M., \& Chan, C. T. (2016). How to Begin a Quality Improvement Project. 11(1), 893-900. https://doi.org/10.2215/CJN.11491015

Smits, W., Buiten, M. Van, \& Hartmann, T. (2016). Yield-to-BIM : impacts of BIM maturity on project performance. Building Research \& Information, 3218(June). https://doi.org/10.1080/09613218.2016.1190579

Sunindijo, R. Y. (2015). Project Manager Skills for Improving Project Performance. International Journal of Business Performance Management, 16(1), 67-83. https://doi.org/10.1504/IJBPM.2015.066041

Suprapto, M., Bakker, H. L. M., Mooi, H. G., \& Hertogh, M. J. C. M. (2015). How do contract types and incentives matter to project performance ? JPMA.

https://doi.org/10.1016/j.ijproman.2015.08.003

Thompson, R. C., Su, Y., \& Lucko, G. (2017). Measuring Project Performance Inspired by Stock Index. 196(June), 706-713. https://doi.org/10.1016/j.proeng.2017.07.237

Unterhitzenberger, C., \& Bryde, D. J. (2018). Organizational Justice, Project Performance, and the Mediating Effects of Key Success Factors. Project Management Journal, 50(1), 1-14. https://doi.org/10.1177/8756972818808984

Van Lancker, J., Mondelaers, K., Wauters, E., \& Van Huylenbroeck, G. (2016). The Organizational Innovation System: A systemic framework for radical innovation at the organizational level. Technovation, 52-53, 40-50.

https://doi.org/10.1016/j.technovation.2015.11.008

Wang, Y., Liu, Y., \& Canel, C. (2018). Process coordination, project attributes and project performance in offshore-outsourced service projects. International Journal of Project Management, 36(7), 980-991. https://doi.org/10.1016/j.ijproman.2018.02.005

Wiese, C. W., \& Florida, C. (2015). Teamwork and Team Performance Measurement. In International Encyclopedia of Social \& Behavioral Sciences (Second Edi, Vol. 24). Elsevier. https://doi.org/10.1016/B978-0-08-097086-8.22017-5

Willar, D. (2017). Developing attributes for evaluating construction project- based performance. The TQM Journal, 29(2), 369-384. https://doi.org/10.1108/TQM-042016-0036

Winter, R., \& Chaves, M. (2017). Innovation in the management of lessons learned in an IT project with the adoption of social media. International Journal of Innovation, 5(2), 156170. https://doi.org/10.5585/iji.v5i2.155

Wisdom, J. P., Chor, K. H. B., Hoagwood, K. E., \& Horwitz, S. M. (2014). Innovation adoption: A review of theories and constructs. Administration and Policy in Mental Health and Mental Health Services Research, 41(4), 480-502. https://doi.org/10.1007/s10488-0130486-4

Xiang, C., Yang, Z., \& Zhang, L. (2016). Improving IS development teams' performance during requirement analysis in project-The perspectives from shared mental model and emotional intelligence. International Journal of Project Management, 34(7), 12661279. https://doi.org/10.1016/J.IJPROMAN.2016.06.009 
Yang, L. (2017). Requirements Engineering Practice to Improve Project Performance and Competitive Advantage. IJSMS, 2(3), 24178. https://doi.org/10.24178/ijsms.2017.2.3.01

Yu, S., \& Cheng, C. (2014). The mediating role of organizational justice on the relationship between administrative performance appraisal practices and organizational commitment. The International Journal of Human Resource Management, 25(8), 11311148. https://doi.org/10.1080/09585192.2013.816864

Yun, S., Choi, J., Oliveira, D. P. De, \& Mulva, S. P. (2015). Development of performance metrics for phase-based capital project benchmarking. JPMA, 34(3), 389-402. https://doi.org/10.1016/j.ijproman.2015.12.004

Zailani, S., Govindan, K., Iranmanesh, M., \& Shaharudin, M. R. (2015). Green innovation adoption in automotive supply chain: The Malaysian case. Journal of Cleaner Production, 108, 1115-1122. https://doi.org/10.1016/j.jclepro.2015.06.039

Zidane, Y. J., Hussein, B. A., \& Ørn, J. (2016). Categorization of organizational factors and their impact on project performance. Procedia - Social and Behavioral Sciences, 226(1877), 162-169. https://doi.org/10.1016/j.sbspro.2016.06.175 